\title{
Prevalence and correlates of infrequent and frequent bullying victimization among school adolescents from five Southeast Asian countries
}

Supa Pengpid ${ }^{1,2}$ and Karl Peltzer ${ }^{3}$

\author{
${ }^{1}$ ASEAN Institute for Health Development, Mahidol University, Salaya, Phutthamonthon, \\ Nakhon Pathom, Thailand \\ ${ }^{2}$ Department of Research Administration and Development, University of Limpopo, Turfloop, \\ South Africa \\ ${ }^{3}$ Department of Psychology, University of the Free State, Bloemfontein, South Africa \\ Corresponding author at: Karl Peltzer, University of the Free State, Bloemfontein, South \\ Africa; Email: kfpeltzer@gmail.com
}

\begin{abstract}
The study aimed to assess the prevalence and its correlates of infrequent and frequent bullying victimization (=BV) among school-going adolescents in five "Association of Southeast Asian Nations" (ASEAN) member states. The cross-sectional sample comprised 33,184 school adolescents (14.6 years mean age) from five ASEAN countries of the "Global School-based Student Health Survey" (GSHS) in 2015. Results indicate that $30.6 \%$ of participants reported any past-month BV, $33.9 \%$ in boys and 27.5 in girls, ranging from $11.8 \%$ in Laos to $48.7 \%$ in the Philippines. In the adjusted multinomial logistic regression analysis, students from the Philippines and Thailand, experience of hunger, sedentary behaviour, attending physical education classes, being underweight, being overweight or obese, ever amphetamine use, physically assaulted, school truancy, participation in a physical fight, injury, low peer support and psychological distress were associated with BV. Almost one in three adolescents were bullied and several associated variables were identified which can assist in targeting the strategies of intervention.
\end{abstract}

Key words: Bullying victimization, risk factors, protective factors, adolescents, Asia 


\section{Introduction}

"Bullying refers to aggressive behavior that is repetitive and intentional in which a power differential exists between the victim and bully. The negative effects of bullying on an individual's mental and physical health are substantial and in line with other major forms of child maltreatment." [1] (p.235) Bullying victimization (=BV) can be better prevented if the epidemiology and determinants are known in a given population [1]. Globally, there is a high proportion of BV among adolescents (about 30\% past month) [2], ranging from $50.9 \%$ (past month) in Nepal [3], 45.0\% (past month) in 2011 in the Philippines [4], 41.3\% (past month) in Pakistan [5], 44.6\% (past year) in China [6], to 27.8\% (past month) in Thailand [7] in Asian countries. There is limited recent information on the prevalence and correlates of BV among adolescents in ASEAN countries [8].

Sociodemographic, externalizing and internalizing factors have been identified as correlates of BV. Sociodemographic correlates of BV victimization include younger age groups, boys and lower socioeconomic status [6,7,9]. Externalizing symptoms increasing the odds of BV may include substance use, violence, injury, and truancy [6,7,9]. Internalizing symptoms increasing the odds of BV may include mental distress, no close friends, and sedentary behaviour $[6,7,9]$. Furthermore, parental and peer support have been identified as protective against BV [10,11]. The investigation aimed to estimate the prevalence and correlates of BV among in-school adolescents in five ASEAN countries.

\section{Methods}

\section{Participants and procedures}

This study uses cross-sectional data from the 2015 ASEAN "Global School-based Student Health Survey (GSHS)". Using a two-stage cluster sampling strategy, nationally representative samples of middle school students were produced in Indonesia, Laos, the Philippines, Thailand, and Timor-Leste in 2015 [12]. "Under the supervision of trained survey administrators, students completed a self-administered questionnaire in their language during classroom periods" [12]. "The study proposal was approved by the Ministry of Education or Health and a national ethics committee, and verbal or written consent was obtained from the participating schools, parents, and students before the survey was administered." [12].

\section{Measures}

The GSHS study measured used is shown in Table 1 [12]. BV was assessed with the question 
"During the past 30 days, on how many days were you bullied?" (number of days) [12]. Infrequent BV was defined as 1-2 days/month and frequent BV as 3-30 days/month.

[12]. The "psychological distress items (no close friends, loneliness, anxiety, suicidal ideation and suicide attempt) were summed, and grouped into $0=0,1=1$ single and 2-5=2 multiple" [13]. Underweight was defined "as less than -2SD from the median for BMI by age and sex", and overweight or obesity was classified as "more than +1 standard deviation (SD) from the median body mass index by age and sex." [14] The "four items on parental or guardian support were summed, and classified into three groups, 0-1 low, 2 medium and 3-4 high support" [13]. "Sedentary behaviour was defined as spending 3 or more hours per day sitting" [15].

Table 1: Description of questions

\begin{tabular}{|c|c|c|}
\hline Variables & Items & Responses (coding) \\
\hline Age & "How old are you?" & $\begin{array}{l}\text { "11 years old or younger to } 18 \\
\text { years old or older" }\end{array}$ \\
\hline Gender & "What is your sex?" & "Male, Female" \\
\hline Economic status & $\begin{array}{l}\text { "During the past } 30 \text { days, how often did you go hungry because there was not } \\
\text { enough food in your home?" }\end{array}$ & $\begin{array}{l}" 1=\text { never to } 5=\text { always }(\text { coded } \\
1-3=0 \text { and } 4-5=1) "\end{array}$ \\
\hline $\begin{array}{l}\text { Bullying } \\
\text { victimization }\end{array}$ & $\begin{array}{l}\text { "[Bullying occurs when a student or a group of students say or do bad and } \\
\text { unpleasant things to another student. It is also bullying when a student is teased a } \\
\text { lot in an unpleasant way or a student is forced to withdraw from certain activities } \\
\text { on purpose. It is not bullying when two students of about the same strength or } \\
\text { power argue or fight or when teasing is done in a friendly and hilarious way.]" } \\
\text { "During the past } 30 \text { days, on how many days were you bullied?" }\end{array}$ & $\begin{array}{l}\text { " } 1=0 \text { days to } 7=\text { All } 30 \text { days } \\
\text { (coded } 1=1,2=2 \text { and } 3-7=3 \text { )" }\end{array}$ \\
\hline Sedentary behaviour & $\begin{array}{l}\text { "How much time do you spend during a typical or usual day sitting and watching } \\
\text { television, playing computer games, talking with friends, or doing other sitting } \\
\text { activities, such as country examples?" }\end{array}$ & $\begin{array}{l}\text { " } 1=\text { less than } 1 \text { hour per day; } 2=1- \\
2 \mathrm{hrs} / \text { day; } 3=3-4 \mathrm{hrs} / \text { day; } 4=5-6 \\
\mathrm{hrs} / \text { day; } 5=7-8 \mathrm{hrs} / \text { day and } 6=8 \\
\text { or more hours per day" }\end{array}$ \\
\hline $\begin{array}{l}\text { Physical education } \\
(\geq 3 \text { days/week) }\end{array}$ & $\begin{array}{l}\text { "During this school year, on how many days did you go to physical education (PE) } \\
\text { class each week?" }\end{array}$ & $\begin{array}{l}\text { " } 1=0 \text { days to } 6=5 \text { or more days } \\
\text { (coded } 1-3=0 \text { and } 4-6=1 \text { )" }\end{array}$ \\
\hline Height & "How tall are you without your shoes on?" & \\
\hline Weight & "How much do you weigh without your shoes on?" & \\
\hline Current tobacco use & $\begin{array}{l}\text { "During the past } 30 \text { days, on how many days did you smoke cigarettes/use any } \\
\text { tobacco products other than cigarettes, such as ... country examples?" }\end{array}$ & $\begin{array}{l}" 1=0 \text { days to } 7=\text { All } 30 \text { days } \\
\text { (coded } 1=0 \text { and } 2-7=1) "\end{array}$ \\
\hline Amphetamine use & $\begin{array}{l}\text { "During your life, how many times have you used amphetamines or } \\
\text { methamphetamines?" }\end{array}$ & $\begin{array}{l}" 1=0 \text { times to } 5=20 \text { or more } \\
\text { times (coded } 1=0 \text { and } 2-5=1) "\end{array}$ \\
\hline Truancy & $\begin{array}{l}\text { "During the past } 30 \text { days, on how many days did you miss classes or school without } \\
\text { permission?" }\end{array}$ & $\begin{array}{l}" 1=0 \text { days to } 5=10 \text { or more days } \\
\text { (coded } 1=0 \text { and } 2-5=1) "\end{array}$ \\
\hline Physical assault & "During the past 12 months, how many times were you physically attacked?" & $\begin{array}{l}\text { " } 1=0 \text { times to } 8=12 \text { or more } \\
\text { times" }\end{array}$ \\
\hline Physical fights & "During the past 12 months, how many times were you in a physical fight?" & $\begin{array}{l}\text { " } 1=0 \text { times to } 8=12 \text { or more } \\
\text { times" }\end{array}$ \\
\hline Injury & "During the past 12 months, how many times were you seriously injured?" & $\begin{array}{l}" 1=0 \text { times to } 8=12 \text { or more } \\
\text { times (coded } 1=0 \text { and } 2-8=1) "\end{array}$ \\
\hline \multicolumn{3}{|l|}{ Psychological distress } \\
\hline No close friends & "How many close friends do you have?" & $\begin{array}{l}" 1=0 \text { to } 4=3 \text { or more }(\text { coded } \\
1+=0,0=1) "\end{array}$ \\
\hline Lonely & "During the past 12 months, how often have you felt lonely?" & $\begin{array}{l}" 1=\text { never to } 5=\text { always }(\text { coded } 1- \\
3=0 \text { and } 4-5=1) "\end{array}$ \\
\hline Worry & $\begin{array}{l}\text { "During the past } 12 \text { months, how often have you been so worried about something } \\
\text { that you could not sleep at night?" }\end{array}$ & $\begin{array}{l}" 1=\text { never to } 5=\text { always (coded } 1- \\
3=0 \text { and } 4-5=1) "\end{array}$ \\
\hline Suicidal ideation & "During the past 12 months, did you ever seriously consider attempting suicide?" & "Yes, No" \\
\hline \multirow[t]{2}{*}{ Suicide attempt } & "During the past 12 months, how many times did you actually attempt suicide?" & $\begin{array}{l}" 1=0 \text { times to } 5=6 \text { or more times } \\
\text { (coded } 1=0 \text { and } 2-5=1) "\end{array}$ \\
\hline & Social and family related protective indicators & \\
\hline Peer support & $\begin{array}{l}\text { "During the past } 30 \text { days, how often were most of the students in your school kind } \\
\text { and helpful?" }\end{array}$ & $\begin{array}{l}\text { " } 1=\text { never to } 5=\text { always }(\text { coded } 1- \\
3=0 \text { and } 4-5=1) "\end{array}$ \\
\hline Parental supervision & $\begin{array}{l}\text { "During the past } 30 \text { days, how often did your parents or } \\
\text { guardians check to see if your homework was done?" }\end{array}$ & $\begin{array}{l}" 1=\text { never to } 5=\text { always (coded } 1- \\
3=0 \text { and } 4-5=1) "\end{array}$ \\
\hline
\end{tabular}




\begin{tabular}{lll}
\hline $\begin{array}{l}\text { Parental } \\
\text { connectedness }\end{array}$ & $\begin{array}{l}\text { "During the past 30 days, how often did your parents or } \\
\text { guardians understand your problems and worries?" }\end{array}$ & $\begin{array}{c}\text { "1=never to 5=always (coded 1- } \\
3=0 \text { and 4-5=1)" }\end{array}$ \\
\hline \multirow{2}{*}{ Parental bonding } & $\begin{array}{l}\text { "During the past 30 days, how often did your parents or guardians really know } \\
\text { what you were doing with your free time?" }\end{array}$ & $\begin{array}{c}\text { " } 1=\text { never to 5=always (coded 1- } \\
3=0 \text { and 4-5=1)" }\end{array}$ \\
\hline $\begin{array}{l}\text { Parental respect for } \\
\text { privacy }\end{array}$ & $\begin{array}{l}\text { "During the past 30 days, how often did your parents or guardians go through your } \\
\text { things without your approval?" }\end{array}$ & $\begin{array}{c}\text { "1=never to 5=always (coded 1- } \\
3=0 \text { and 4-5=1)" }\end{array}$ \\
\hline
\end{tabular}

\section{Data analysis}

Statistical analyses were conducted with "STATA software version 15.0 (Stata Corporation, College Station, Texas, USA), taking the complex sampling design of the study into account". Frequencies, percentages, and means were used to describe the study characteristics. Multinomial logistic regression was used to predict infrequent and frequent BV, with no BV as the reference category. Only complete cases were included in the analysis, and $p<0.05$ indicated significance.

\section{Results}

\section{Sample characteristics}

The overall sample comprised 33,184 school adolescents with a mean age of 14.6 years $(\mathrm{SD}=1.7)$ from Indonesia "(overall response rate=94\%), Laos (72\%), Philippines (79\%), Thailand (89\%) and Timor-Leste (response rate=79\%)" [12]. Almost one in three participants (30.6\%) reported any BV in the past 30 days (33.9\% in boys and 27.5 in girls). The prevalence of past month BV ranged from $11.8 \%$ in Laos to $48.7 \%$ in the Philippines. Almost one in five students $(18.6 \%)$ reported BV on one to two days in the past month and $12.0 \%$ on three to 30 days in the past month (see Table 2).

Table 2: Sample and bullying victimization (BV) characteristics

\begin{tabular}{|l|l|l|l|}
\hline Variable & Sample & $\begin{array}{l}\text { Infrequent } \\
\text { BV }\end{array}$ & Frequent BV \\
\hline & $\mathrm{N}(\%)$ & $\mathrm{N}(\%)$ & $\mathrm{N}(\%)$ \\
\hline Socio-demographics & & & \\
\hline All & 33184 & 18.6 & 12.0 \\
\hline Country & & & \\
Indonesia & $11142(33.6)$ & 13.9 & 6.7 \\
Laos & $3683(11.1)$ & 9.3 & 2.5 \\
Philippines & $8761(26.4)$ & 28.2 & 20.5 \\
Thailand & $5894(17.8)$ & 15.6 & 13.7 \\
Timor-Leste & $3704(11.2)$ & 21.5 & 7.1 \\
\hline
\end{tabular}




\begin{tabular}{|c|c|c|c|}
\hline $\begin{array}{l}\text { Age (years) } \\
\leq 13 \\
14 \\
15 \\
\geq 16\end{array}$ & $\begin{array}{l}9611(29.1) \\
6826(20.7) \\
6396(19.4) \\
10217(30.9)\end{array}$ & $\begin{array}{l}18.3 \\
19.7 \\
20.6 \\
16.7\end{array}$ & $\begin{array}{l}12.2 \\
12.5 \\
12.8 \\
10.5\end{array}$ \\
\hline $\begin{array}{l}\text { Gender } \\
\text { Female } \\
\text { Male }\end{array}$ & $\begin{array}{l}17991(51.1) \\
14902(48.9)\end{array}$ & $\begin{array}{l}17.6 \\
19.8\end{array}$ & $\begin{array}{l}9.6 \\
14.1\end{array}$ \\
\hline $\begin{array}{l}\text { Hunger } \\
\text { Never } \\
\text { Rarely } \\
\text { Sometimes/mostly/always }\end{array}$ & $\begin{array}{l}13808(40.4) \\
6346(20.0) \\
12885(39.6)\end{array}$ & $\begin{array}{l}13.8 \\
20.8 \\
22.6\end{array}$ & $\begin{array}{l}8.7 \\
14.0 \\
14.3\end{array}$ \\
\hline Risk behaviour & & & \\
\hline Sitting 3 or more hours (during leisure-time) & $9822(32.6)$ & 17.4 & 15.1 \\
\hline Attending physical education classes & $7634(22.8)$ & 24.7 & 17.3 \\
\hline $\begin{array}{l}\text { Body Mass Index } \\
\text { Normal } \\
\text { Underweight } \\
\text { Overweight or obese }\end{array}$ & $\begin{array}{l}23540(77.3) \\
2825(8.7) \\
3780(14.0) \\
\end{array}$ & $\begin{array}{l}17.7 \\
20.0 \\
15.9 \\
\end{array}$ & $\begin{array}{l}10.8 \\
13.0 \\
15.9 \\
\end{array}$ \\
\hline Current tobacco use & $4575(13.9)$ & 26.3 & 22.4 \\
\hline Current alcohol use & $4883(12.5)$ & 26.9 & 22.6 \\
\hline Ever amphetamine use & $963(3.0)$ & 34.6 & 39.7 \\
\hline School truancy & $9231(25.3)$ & 25.4 & 18.8 \\
\hline Physically attacked & $10306(33.1)$ & 28.0 & 21.4 \\
\hline In physical fight & $8734(28.0)$ & 30.4 & 23.4 \\
\hline Sustained injury & $10624(36.9)$ & 27.9 & 21.5 \\
\hline $\begin{array}{l}\text { Psychological distress } \\
0 \\
1 \\
2-3\end{array}$ & $\begin{array}{l}23816(76.8) \\
5041(14.6) \\
2844(8.6)\end{array}$ & $\begin{array}{l}16.0 \\
25.8 \\
27.9\end{array}$ & $\begin{array}{l}7.6 \\
19.1 \\
30.6\end{array}$ \\
\hline Social-familial protective indicators & & & \\
\hline High peer support & $1112(36.8)$ & 15.2 & 9.8 \\
\hline $\begin{array}{l}\text { Parental support } \\
0-1 \\
2 \\
3-4\end{array}$ & $\begin{array}{l}17139(51.6) \\
8479(27.0) \\
6326(21.4) \\
\end{array}$ & $\begin{array}{l}21.0 \\
17.7 \\
14.8 \\
\end{array}$ & $\begin{array}{l}13.8 \\
10.0 \\
9.1\end{array}$ \\
\hline
\end{tabular}

\section{Associations with bullying victimization}

In the adjusted multinominal logistic regression analysis, students from the Philippines and Thailand, experience of hunger, sedentary behaviour, attending physical education classes, being underweight, being overweight or obese, ever amphetamine use, school truancy, physically attacked, injury, involvement in physical fighting, and psychological distress were positively associated with infrequent and/or frequent BV. Being from Laos and Timor-Leste and peer support decreased the odds of infrequent and/or frequent BV (see Table 3). 
Table 3: Associations with bullying victimization (BV) frequency

\begin{tabular}{|c|c|c|c|c|}
\hline Variable & Infrequent BV & Frequent BV & Infrequent BV & Frequent BV \\
\hline & URRR (95\% CI) & URRR $(95 \%$ CI) & ARRR $(95 \% \mathrm{CI})$ & ARRR $(95 \%$ CI $)$ \\
\hline \multicolumn{5}{|l|}{ Sociodemographic indicators } \\
\hline $\begin{array}{l}\text { Country } \\
\text { Indonesia } \\
\text { Laos } \\
\text { Philippines } \\
\text { Thailand } \\
\text { Timor-Leste } \\
\end{array}$ & $\begin{array}{l}1 \text { (Reference) } \\
0.60(0.22,0.52)^{* * *} \\
3.14(2.68,3.66)^{* * *} \\
1.26(1.05,1.51)^{*} \\
1.72(1.44,2.04)^{* * *}\end{array}$ & $\begin{array}{l}1 \text { (Reference) } \\
0.34(0.22,0.52)^{* * *} \\
4.72(2.97,5.61)^{* * *} \\
2.30(1.78,2.96)^{* * *} \\
1.19(0.91,1.55)\end{array}$ & $\begin{array}{l}1 \text { (Reference) } \\
0.69(0.54,0.88)^{* *} \\
2.28(1.93,2.68)^{* * *} \\
1.17(0.99,1.38)) \\
1.09(0.88,1.34)\end{array}$ & $\begin{array}{l}1 \text { (Reference) } \\
0.54(0.35,0.85)^{* *} \\
3.48(2.80,4.34)^{* * *} \\
1.64(1.32,2.03)^{* * *} \\
0.69(0.52,0.92)^{*}\end{array}$ \\
\hline $\begin{array}{l}\text { Age (years) } \\
\leq 13 \\
14 \\
15 \\
\geq 16\end{array}$ & $\begin{array}{l}1 \text { (Reference) } \\
1.10(0.97,1.26) \\
1.17(0.96,1.43) \\
0.87(0.72,1.05)\end{array}$ & $\begin{array}{l}1 \text { (Reference) } \\
1.05(0.89,1.24) \\
1.10(0.91,1.32) \\
0.83(0.66,1.04)\end{array}$ & - & 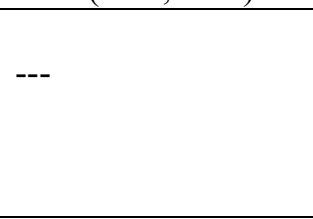 \\
\hline $\begin{array}{l}\text { Gender } \\
\text { Female } \\
\text { Male }\end{array}$ & $\begin{array}{l}1 \text { (Reference) } \\
1.23(1.11,1.36)^{* * *}\end{array}$ & $\begin{array}{l}1 \text { (Reference) } \\
1.55(1.32,1.82)^{* * *}\end{array}$ & $\begin{array}{l}1 \text { (Reference) } \\
0.95(0.86,1.06)\end{array}$ & $\begin{array}{l}1 \text { (Reference) } \\
1.16(0.96,1.41)\end{array}$ \\
\hline $\begin{array}{l}\text { Experience of hunger } \\
\text { Never } \\
\text { Rarely } \\
\text { Sometimes/mostly/always } \\
\end{array}$ & $\begin{array}{l}1 \text { (Reference) } \\
1.80(1.62,2.01)^{* * *} \\
2.02(1.85,2.21)^{* * *}\end{array}$ & $\begin{array}{l}1 \text { (Reference) } \\
1.91(1.62,2.25)^{* * *} \\
2.02(1.77,2.30)^{* * *}\end{array}$ & $\begin{array}{l}1 \text { (Reference) } \\
1.22(1.08,1.39)^{* *} \\
1.61(1.44,1.80)^{* * *}\end{array}$ & $\begin{array}{l}1 \text { (Reference) } \\
1.16(0.99,1.36) \\
1.50(1.30,1.73)^{* * *}\end{array}$ \\
\hline Risk behaviour & & & & \\
\hline $\begin{array}{l}\text { Sitting } 3 \text { or more hours (during } \\
\text { leisure-time) }\end{array}$ & $0.94(0.85,1.05)$ & $1.52(1.33,1.73)^{* * *}$ & $0.91(0.80,1.03)$ & $1.40(1.21,1.61)^{* * *}$ \\
\hline Attending physical education classes & $1.83(1.64,2.03)^{* * *}$ & $2.10(1.85,2.37)^{* * *}$ & $1.26(1.11,1.44)^{* * *}$ & $1.29(1.07,1.55)^{* *}$ \\
\hline $\begin{array}{l}\text { Body mass index } \\
\text { Normal } \\
\text { Underweight } \\
\text { Overweight or obese }\end{array}$ & $\begin{array}{l}1 \text { (Reference) } \\
1.21(1.05,1.39)^{*} \\
0.89(0.78,1.01)\end{array}$ & $\begin{array}{l}1 \text { (Reference) } \\
1.29(1.10,1.50)^{* *} \\
1.09(0.01,1.31)\end{array}$ & $\begin{array}{l}1 \text { (Reference) } \\
1.22(1.00,1.48)^{*} \\
0.98(0.83,1.17)\end{array}$ & $\begin{array}{l}1 \text { (Reference) } \\
1.24(1.04,1.47)^{*} \\
1.30(1.08,1.57)^{* *}\end{array}$ \\
\hline Current tobacco use & $2.13(1.69,2.68)^{* * *}$ & $3.04(2.39,3.88)^{* * *}$ & $1.17(0.95,1.41)$ & $1.04(0.82,1.32)$ \\
\hline Current alcohol use & $2.23(1.87,2.65)^{* * *}$ & $3.19(2.53,4.01)^{* * *}$ & $1.07(0.89,1.28)$ & $0.86(0.71,1.05)$ \\
\hline Ever amphetamine use & $5.30(3.41,8.23)^{* * *}$ & $10.03(7.08,14.24)^{* * *}$ & $1.79(1.08,2.96)^{*}$ & $1.96(1.11,3.46)^{*}$ \\
\hline School truancy & $2.04(1.79,2.33)^{* * *}$ & $2.56(2.18,3.00)^{* * *}$ & $1.18(1.04,1.33)^{* *}$ & $1.14(0.97,1.35)$ \\
\hline
\end{tabular}




\begin{tabular}{|l|l|l|l|l|}
\hline Physically attacked & $3.08(2.77,3.43)^{* * *}$ & $4.44(3.94,5.01)^{* * *}$ & $1.93(1.72,2.17)^{* * *}$ & $2.39(2.06,2.76)^{* * *}$ \\
\hline In physical fight & $3.61(3.22,4.06)^{* * *}$ & $5.19(4.51,5.98)^{* * *}$ & $1.77(1.54,2.03)^{* * *}$ & $2.03(1.70,2.43)^{* * *}$ \\
\hline Sustained injury & $3.53(3.14,3.97)^{* * *}$ & $5.52(4.71,6.48)^{* * *}$ & $1.99(1.77,2.24)^{* * *}$ & $2.33(2.03,2.67)^{* * *}$ \\
\hline $\begin{array}{l}\text { Psychological distress } \\
0\end{array}$ & 1 (Reference) & 1 (Reference) & 1 (Reference) & $1($ Reference) \\
1 & $2.24(1.95,2.57)^{* * *}$ & $3.49(2.99,4.07)^{* * *}$ & $1.57(1.35,1.84)^{* * *}$ & $2.16(1.85,2.51)^{* * *}$ \\
$2-3$ & $3.20(2.74,3.75)^{* * *}$ & $7.41(6.29,8.71)^{* * *}$ & $1.74(1.46,2.08)^{* * *}$ & $3.47(2.87,4.19)^{* * *}$ \\
\hline Social-familial indicators & & & & \\
\hline High peer support & $0.64(0.57,0.72)^{* * *}$ & $0.66(0.58,0.74)^{* * *}$ & $0.79(0.70,0.89)^{* * *}$ & $0.870 .74,1.02)$ \\
\hline Parental support & & & & $1($ Reference) \\
$0-1$ & 1 Reference) & 1 (Reference) & $1($ Reference $)$ & $0.94(0.80,1.11)$ \\
2 & $0.76(0.67,0.87)^{* * *}$ & $0.65(0.57,0.75)^{* * *}$ & $1.00(0.89,1.13)$ & $0.94(0.79,1.12)$ \\
$3-4$ & $0.61(0.53,0.70)^{* * *}$ & $0.56(0.48,0.66)^{* * *}$ & $0.92(0.81,1.06)$ & \\
\hline
\end{tabular}

URRR=Unadjusted Relative Risk Ratio; ARRR=Adjusted Relative Risk Ratio; $\mathrm{CI}=$ Confidence Interval; $* * * \mathrm{P}<.001 ; * * \mathrm{P}<.01 ; * \mathrm{P}<.05$ 


\section{Discussion}

The investigation assessed the prevalence and correlates of $\mathrm{BV}$ among school adolescents in five ASEAN countries. The overall prevalence of BV (30.6\%) was similar to the global prevalence (30\%) [2], and lower than in Nepal (50.9\%) [3], and Pakistan (41.3\%) [5]. The prevalence of past-month BV of $29.3 \%$ in Thailand was similar to the 2008 Thailand GSHS (27.8\%) [7], of 48.7\% in the Philippines was higher than in the 2003 to 2011 Philippines GSHS (34.7\%-45.0\%) [7], and of 20.6\% in Indonesia was much lower than in the 2007 Indonesia GSHS (50.0\%) [16]. It is possible that school-based anti-bullying interventions in Indonesia have been effective in reducing BV [17]. Among the five ASEAN study countries, Laos had the lowest prevalence of BV (11.8\%). These figures may compare with the prevalence of any physical violence victimization among adolescents (13-17 years) (8.2\% in boys and 6.6\% in girls) in the past 12 months from "Violence against Children Survey in Laos" in 2014 [18]. The lower prevalence of BV among adolescents in Laos may be attributed to specific cultural norms and practices in Laos, and the relatively high prevalence in Timor-Leste may be attributed due to effects of a long history of conflict [19].

Consistent with some previous studies [6,20], this study found that the experience of hunger (or lower socioeconomic status) was associated with BV. Unlike some previous studies $[21,22]$, this study did not find significant sex and age differences in the prevalence of BV. Further research is needed to explore the nonsignificant age and sex differences.

Consistent with previous findings [7,21,23-25], this study found an association between externalizing symptoms (ever amphetamine use, school truancy, physically attacked, in a physical fight, and injury), internalizing symptoms (psychological distress and sedentary behaviour) and BV. Steenberg, Palic and Elklit [26] note that "victims of bullying generally lack in the use of adaptive coping strategies making students with high externalizing and internalizing symptoms more vulnerable to BV." On the other hand, adolescents who are being bullied may consequently develop more externalizing and internalizing symptoms [22,24].

Some previous studies among adolescents $[10,11]$ found parental support protective against BV, while in this study this was found in bivariate analysis but was no longer significant in the multivariable model. Peer support was protective against infrequent BV. This finding is consistent with a previous review where positive peer interaction was the "strongest protective factor against being a bully/victim." [27]. In this study, the attendance of physical education increased the odds for BV, while in another study "BV was associated with fewer days in physical education." [28]. It is possible that in our study attending physical education classes increased the risk of BV. Consistent with a large previous study [29], this survey showed that 
both underweight and overweight/obesity were associated with BV. Previous research showed that "weight stigmatization translates into pervasive victimization, teasing, and bullying." [30].

Study strengths included the large nationally representative adolescent school samples and the uniform GSHS methodology applied in the five study countries. Study limitations include the self-report of the data, the cross-sectional design, and the focus on school adolescents.

\section{Conclusion}

The study found among school-going adolescents across five ASEAN countries that almost one in three adolescents were bullied in the past month. Several risk factors for BV were identified, including hunger or food insecurity, sedentary behaviour, attending physical education classes, being underweight, being overweight or obese, ever amphetamine use, physically attacked, in a physical fight, injury, truancy, psychological distress and low peer support, which can assist in designing intervention strategies in this adolescent school population.

Author Contributions: "All authors fulfill the criteria for authorship. S.P. and K.P. conceived and designed the research, performed statistical analysis, drafted the manuscript and made critical revisions of the manuscript for key intellectual content. All authors have read and agreed to the published version of the manuscript."

Funding: "This research received no external funding."

Acknowledgments: "The data source, the World Health Organization NCD Microdata Repository (URL: https:

//extranet.who.int/ncdsmicrodata/index.php/catalog), is hereby acknowledged."

Conflict of Interest: "The authors declare no conflict of interest."

\section{References}

1. Rettew DC, Pawlowski S. Bullying. Child Adolesc Psychiatr Clin N Am. 2016;25(2):23542. doi: 10.1016/j.chc.2015.12.002

2. Elgar, F. J., McKinnon, B., Walsh, S. D., Freeman, J. D., Donnelly, P., de Matos, M.G., ... Currie, C.. (2015). Structural determinants of youth bullying and fighting in 79 
countries. Journal of Adolescent Health, 57(6), 643-50. doi: 10.1016/j.jadohealth.2015.08.007.

3. Rahman MM, Rahman MM, Khan MMA, Hasan M, Choudhury KN. Bullying victimization and adverse health behaviors among school-going adolescents in South Asia: Findings from the global school-based student health survey. Depress Anxiety. 2020;10.1002/da.23033. doi:10.1002/da.23033

4. Peltzer, K., \& Pengpid, S. (2015). Health risk behaviour among in-school adolescents in the Philippines: Trends between 2003, 2007 and 2011, A cross-sectional study. International Journal of Environmental Research and Public Health, 13(1), 73. doi: 10.3390/ijerph13010073.

5. Shaikh, M. A. (2013). Bullying victimization among school-attending adolescents in Pakistan. Journal of the Pakistan Medical Association, 63(9), 1202-3.

6. Zhu, Y., \& Chan, K. L. (2015). Prevalence and correlates of school bullying victimization in Xi'an, China. Violence and Victims, 30(4), 714-32.

7. Pengpid, S., \& Peltzer, K. (2013). Bullying and its associated factors among schoolaged adolescents in Thailand. ScientificWorldJournal, 2013:254083. doi: $10.1155 / 2013 / 254083$.

8. Sittichai, R., \& Smith, P. K. (2015). Bullying in South-East Asian countries: a review. Aggression and Violent Behavior, 23, 22-35

9. Seo, H. J., Jung, Y. E., Kim, M. D., \& Bahk, W. M. (2017). Factors associated with bullying victimization among Korean adolescents. Neuropsychiatric Disease and Treatment, 13, 2429-2435. doi: 10.2147/NDT.S140535. eCollection 2017.

10. Abdirahman, H., Fleming, L. C., \& Jacobsen, K. H. (2013). Parental involvement and bullying among middle-school students in North Africa. Eastern Mediterranean Health Journal, 19(3), 227-33.

11. Boel-Studt, S., \& Renner, L. M. (2013). Individual and familial risk and protective correlates of physical and psychological peer victimization. Child Abuse and Neglect, 37(12), 1163-74. doi: 10.1016/j.chiabu.2013.07.010.

12. World Health Organization (WHO) (2019). Global school-based student health survey (GSHS). URL: https://www.who.int/ncds/surveillance/gshs/en/ (accessed 20 Mar 2019)

13. Pengpid, S., \& Peltzer, K. (2019) Bullying victimization and externalizing and internalizing symptoms among in-school adolescents from five Southeast Asian countries. Children and Youth Services Review, 106, 04473.https://doi.org/10.1016/j.childyouth.2019.104473 
14. Cole, T. J., Bellizzi, M. C., Flegal, K. M., \& Dietz, W. H. (2000). Establishing a standard definition for child overweight and obesity worldwide: international survey. British Medical Journal, 320, 1240-1243.

15. Guthold, R.. Cowan, M. J., Autenrieth, C. S., Kann, L, \& Riley, L. M. (2010). Physical activity and sedentary behavior among schoolchildren: a 34-country comparison. Journal of Pediatrics, 157, 43-49.

16. World Health Organization (WHO) (2007). Global School-based Student Health Survey Indonesia 2007 Fact Sheet. https://www.who.int/ncds/surveillance/gshs/2007_Indonesia_fact_sheet.pdf (accessed 3 May 2019)

17. Sivaraman, B., Nye, E., \& Bowes, L. (2019). School-based anti-bullying interventions for adolescents in low- and middle income countries: A systematic review. Aggression and Violent Behavior, 45, 154-162.

18. National Commission for Mothers and Children, Lao Statistics Bureau and UNICEF Lao PDR (2019). National Violence against Children Survey in Lao PDR. Preliminary Report. Lao PDR: National Commission for Mothers and Children, 2016. URL: https://www.unicef.org/laos/media/1376/file/VAC\%20Report.pdf (accessed 2 May 2019)

19. Silove, D., Brooks, R., Bateman Steel, C. R., Steel, Z., Hewage, K., Rodger, J., \& Soosay, I. (2009). Explosive anger as a response to human rights violations in postconflict Timor-Leste. Social Science and Medicine, 69(5), 670-7. doi: 10.1016/j.socscimed.2009.06.030.

20. Wilson ML, Dunlavy AC \& Berchtold A. 2013 Determinants for Bullying Victimization among 11-16-Year-Olds in 15 Low- and Middle-Income Countries: A Multi-Level Study. Soc. Sci. 2013, 2, 208-220; doi:10.3390/socsci2040208

21. Fleming, L. C., \& Jacobsen, K. H. (2010). Bullying among middle-school students in low and middle income countries. Health Promotion International, 25(1), 73-84. doi: 10.1093/heapro/dap046.

22. Siziya, S., Rudatsikira, E., \& Muula, A. S. (2012). Victimization from bullying among school-attending adolescents in grades 7 to 10 in Zambia. Journal of Injury \& Violence Research, 4(1), 30-5. doi: 10.5249/jivr.v4i1.84.

23. Acquah, E. O., Wilson, M. L., Doku, D. T. (2014). Patterns and correlates for bulling among young adolescents in Ghana. Social Sciences, 3, 827-840. 
24. Arhin, D. K., Oppong Asante, K., Kugbey, N., \& Oti-Boadi, M. (2019). The relationship between psychological distress and bullying victimisation among school-going adolescents in Ghana: a cross-sectional study. BMC Research Notes, 12(1), 264. doi: 10.1186/s13104-019-4300-6.

25. Eastman, M., Foshee, V., Ennett, S., Sotres-Alvarez, D., Reyes, H. L. M., Faris, R., \& North, K. (2018). Profiles of internalizing and externalizing symptoms associated with bullying victimization. Journal of Adolescence, 65, 101-110. doi: 10.1016/j.adolescence.2018.03.007.

26. Steenberg, L. M., Palic, S., \& Elklit, A. (2012). A review of psychological factors related to bullying victimization in schools. Aggression and Violent Behavior, 17, 383-387.

27. Zych, I., Farrington, D. P. \& Ttofi, M. M. (2019). Protective factors against bullying and cyberbullying: A systematic review og meta-analyses. Aggression and Violent Behavior, 45, 4-19.

28. Roman, C. G., \& Taylor, C. J. (2013). A multilevel assessment of school climate, bullying victimization, and physical activity. Journal of School Health, 83(6), 400-7. doi: 10.1111/josh.12043.

29. Lian, Q., Su, Q., Li, R., Elgar, F. J., Liu, Z., \& Zheng, D. (2018). The association between chronic bullying victimization with weight status and body self-image: a cross-national study in 39 countries. PeerJournal, 6, e4330. doi: 10.7717/peerj.4330. eCollection 2018.

30. Puhl, R. M., \& King, K. M. (2013). Weight discrimination and bullying. Best Practice \& Research Clinical Endocrinology \& Metabolism, 27(2), 117-127. doi: 10.1016/j.beem.2012.12.002. 